\title{
Wound Healing Potential of Selected Liverworts Growing in Turkey
}

\author{
Türkiye'de Yetișen Bazı Ciğer Otlarının Yara İyileștirici Etkileri
}

\author{
Alev TOSUN1, İpek SÜNTAR², Hikmet KELEŞ3, Hatice ÖZENOĞLU KIREMiT4, Yoshinori ASAKAWA5 ${ }^{5}$ Esra KÜPELI AKKOL²* \\ 1Ankara University, Faculty of Pharmacy, Department of Pharmacognosy, 06100 Ankara, TURKEY \\ 2Gazi University, Faculty of Pharmacy, Department of Pharmacognosy, 06330 Ankara, TURKEY \\ 3Afyon Kocatepe University, Faculty of Veterinary, Department of Pathology, 03200 Afyonkarahisar, TURKEY \\ ${ }^{4}$ Adnan Menderes University, Faculty of Education, Department of Biology Education, 09010 Aydın, TURKEY \\ 5Tokushima Bunri University, Faculty of Pharmaceutical Sciences, Yamashiro-cho, Tokushima 770-8514, JAPAN
}

\begin{abstract}
The Bryophytes have been traditionally used to cure cuts, burns, external wounds, bacteriosis, pulmonary tuberculosis, neurasthenia, fractures, convulsions, scalds, uropathy, inflammation, fever and pneumonia. Selected eight liverworts growing in Turkey were tested for their wound healing potential. In the present study, in vivo wound-healing activities of the ethereal extracts of some liverworts collected from Southern Anatolia were investigated by using linear incision and circular excision experimental patterns subsequently histopathological analysis. For the bioassays, $1 \%$ ointment formulations were prepared from the crude extracts. The ethereal extracts from Reboulia hemisphaerica (L.) Raddi (Aytoniaceae), Plagiochasma rupestre (J.R. Forst et G. Forst) Steph. (Aytoniaceae), and Targionia hypophylla L. (Targioniaceae) showed 43.1, 38.3, and $24.1 \%$ increase in tensile strength on the linear incision wound test, respectively. The extracts of Reboulia hemisphaerica, Plagiochasma rupestre and Targionia hypophylla also exhibited significant contraction effect with the values of $62.1,58.0$, and $39.8 \%$, respectively, on the circular excision wound model, quite comparable to reference sample. The liverworts have many important biological activities, which are investigated previously. However, the wound healing effects of Turkish liverworts have not been expounded yet. Thus, the results obtained from the present study will be important for the future researches. Moreover, the present study supported the usages of some Bryophytes in some native societies of the world against skin problems, including wound, bruises, burns, etc.
\end{abstract}

Key words: Wound healing, Liverworts, Bryophytes, Marchantiophyta

\section{ÖZ}

Bryofitler geleneksel olarak kesik ve yanık yaralarında, bakteriozis, pulmoner tüberküloz, nevrasteni, kırık, konvülsiyon, üropati, enflamasyon, ateş ve pnömoni tedavisinde kullanılmaktadır. Bu çalışmada, Türkiye'de yetișen ve Anadolu'nun güney kesimlerinden toplanan sekiz ciğer otunun eterli ekstrelerinin in vivo yara iyileştirici etkileri çizgisel insizyon ve dairesel eksiyon yara modelleri kullanılarak araştırıldı. Takibinde dokular üzerinde histopatolojik analizler yapıldı. Deneylerde, ham ekstreden hazırlanan \%1'lik merhem formülasyonları kullanıldı. İnsizyon yara modelinde, Reboulia hemisphaerica (L.) Raddi (Aytoniaceae), Plagiochasma rupestre (J.R. Forst et G. Forst) Steph. (Aytoniaceae) ve Targionia hypophylla L. (Targioniaceae) eterli ekstreleri sırasıyla \%43.1, \%38.3 ve \%24.1 oranlarında yara gerilme kuvvetinde artıș olușturdu. Reboulia hemisphaerica, Plagiochasma rupestre ve Targionia hypophylla ekstreleri sırasıly \%62.1, \%58.0 ve \%39.8 kontraksiyon değerleriyle dairesel eksizyon yara modelinde de referans örnek ile karşılaştırılabilir düzeyde ve anlamlı derecede etkili bulundu. Ciğer otlarının daha önceden belirlenmiş birçok biyolojik etkisi bulunmaktadır. Ancak, Türkiye'de yetișen ciğer otlarının yara iyileștirici etkileri daha önce araștırılmamıștır. Bu nedenle, bu çalışmada elde edilen sonuçlar gelecek araştırmlar için önem taşımaktadır. Bununla beraber, bu çalışma bryofitlerin halk arasında yara ve yanık gibi deri problemlerinde kullanımını doğrulamaktadır.

Anahtar kelimeler: Yara iyileşmesi, Ciğer otları, Bryofitler, Marchantiophyta 


\section{INTRODUCTION}

The medicinal plants and their derivatives have been used for providing relief and cure of illness in traditional forms in all cultures for many years (1-4). Many articles related the biological activity of the plants have been released contemporarily, some part of these studies had been reported for wound-healing activity (5).

The use of wound-healing plants to treat external injuries as well as internal injury is a popular ethnomedicinal practice in many countries such as China, Peru, India and Nigeria (5-9).

The phytochemistry of the Bryophytes has been ignored for a long time because of their morphological small size, unobtrusive position in the nature and difficult taxonomy. Besides of all, they do not have nutritional usages for humans due to their unpleasant taste. However, some Bryophytic plants are used by Native Americans in soup, and as a flavor agent in wine (10). The Bryophytes have also been traditionally used for their medicinal properties in China, Europe and North America, to cure cuts, burns, external wounds, bacteriosis, pulmonary tuberculosis, neurasthenia, fractures, convulsions, scalds, uropathy, inflammation, fever, pneumonia, etc. (10-13).

The Bryophytes are taxonomically placed between algae and pteridophytes. They are classified into three relevant phyla known as Bryophyta (Moss), Marchantiophyta (Liverwort) and Anthocerotophyta (Hornwort). The important group as of the liverworts belongs to Marchantiophyta group are represented by approximately 8000 species in 74 families, 380 genera, and considered to be the oldest aquaticterrestrial primitive plants in the world. The liverworts are used for remedies of cuts, fractures, burns, bruises, wounds and snake bite as mentioned in the literature. Especially during the Renaissance, the liverworts were used in herbal medicines. In China, it is still used to treat the hepatitis and as an external cure to reduce the inflammation. In fact, the most important sides of the liverworts are their structurally and biologically interesting active terpenoid compounds, which are located in oil bodies known as unique organelles of the liverworts. The components isolated from liverworts have significant biological activities such as antimicrobial, antifungal, insect antifeedant, cytotoxic, apoptosis inducing activity, some enzyme inhibitory, neurotic sprouting activity, muscle relaxing, cardiotonic activity and so on (11-13).

Plagiochasma appendiculatum Lehm. et Lind. (Aytoniaceae) distributed in India, is widely used ethnomedicinally by Gaddi tribe in Kangra valley for treating skin diseases in the form of paste, and applied externally for the treatment of burns, boils and blisters on the body. The species is also used for the treatment of skin eruption caused due to bright sun in the summer time (14). Himalayan Indians have used Marchantia polymorpha L. (Marchantiaceae) or M. palmate Nees to treat boils and abscesses because the young archegoniophore resembles an abscess as it emerges from the thallus. Moreover, in China, a mixture of the thallous of Conocephalum conicum L. (Dum.) (Conocephalaceae) and Marchantia polymorpha with vegetable oils is used on bites, boils, burns, cuts, wounds and eczema (10).

The most investigated taxa are from Angiosperms whereas limited data is currently available about Bryophytes. Particularly, there is not enough information about Turkish liverworts in Flora of Turkey (15). Moreover, chemical and biological studies are scarcely limited on these species except for a few studies. Thus, the aim of this study was to evaluate the wound healing activity of the Turkish liverworts by using in vivo models for the preliminary screening. In this frame, the ethereal extracts (Table 1) of the Riccia fluitans L. (Ricciaceae), Porella cordaeana (Huebener) Moore (Porellaceae), Porella platyphylla (L.) Pfeiff. (Porellaceae), Corsinia coriandrina (Spreng.) Lindb. (Corsiniaceae), Mannia androgyna (L.) A. Evans (Aytoniaceae), Reboulia hemisphaerica (L.) Raddi (Aytoniaceae), Plagiochasma rupestre (J.R. Forst et G. Forst) Steph. (Aytoniaceae), Targionia hypophylla L. (Targioniaceae) were debated for healing efficiency on incision and excision wounds models in vivo. In our ongoing research, their chemical constituents will be examined in future studies to find promising agents.

\section{MATERIALS AND METHODS}

\section{Plant materials}

Plant materials were collected from İzmir, Aydın and Muğla provinces, Turkey in 2009. Voucher specimens were identified by $\mathrm{H}$. Ozenoglu Kiremit (Adnan Menderes UniversityDepartment of Biology) and deposited at the Herbarium of Adnan Menderes University in Aydın, Turkey. The list of the species with their collection places and herbarium numbers are presented in Table 1.

\section{Preparation of plant extracts}

The plant extracts were prepared according to Tosun et al., 2013. First of all, dried plant materials were macerated with ether in a dark and cool place for 3-4 weeks. The extracts were filtrated, and the ether was evaporated in vacuo less than $30^{\circ} \mathrm{C}$. The amount of the crude extracts was exactly weighed. The extracts were kept in a freezer up to use in the activity tests (16).

\section{Biological activity tests}

\section{Animals}

Male, Sprague-Dawley rats (160-180 g) and Swiss albino mice (20-25 g) purchased from the animal breeding laboratories of from the animal breeding laboratory of Saki Yenilli (Ankara, Turkey), were used in the experiments. Before the experiments, animals were left for three days at room conditions for acclimatization. They were maintained on standard pellet diet and water ad libitum throughout the experiment. A minimum of six animals was used in each group. 


\section{Preparation of test samples for bioassay}

Test samples of in vivo experimental wound models were prepared in an ointment base (vehicle) consisting of glycol stearate, 1, 2-propylene glycol, liquid paraffin (3:6:1) in 1\% concentration. Immediately, after the wound was created by a surgical blade, animals of the experimental group were topically treated with $0.5 \mathrm{~g}$ of each test ointment. Ointment base was applied to the animals of the vehicle group. Reference group animals were treated with $0.5 \mathrm{~g}$ of Madecassol ${ }^{\circledR}$ (Bayer, 00001199), whereas negative control group animals were not treated with any material.

\section{Wound healing activity}

\section{Linear incision wound model}

All the animals were anaesthetized with 0.05 cc Xylazine (2\% Alfazine ${ }^{\circledR}$ ) and 0.15 cc Ketamine (10\% Ketasol $\left.{ }^{\circledR}\right)$, and the back hairs were shaved with a shaving machine. Two linearparavertebral full-thickness skin incisions of $5 \mathrm{~cm}$ long were made with a sterile surgical blade at the distance of $1.5 \mathrm{~cm}$ from the midline of each side of the vertebral column (17). The incised wounds were sutured by three interrupted sutures of 1 $\mathrm{cm}$ apart. The extracts, the reference drug (Madecasso ${ }^{\circledR}$ ) and the vehicle were topically applied once in a day throughout nine days. Animals of the negative control group were not treated with any material. On the 9th post wound day, all the sutures were removed. Animals were killed under anesthesia on day $10^{\text {th }}$. For the determination of tensile strength of the wound, a linear-paravertebral incised skin sample was measured using a tensiometer (Zwick/Roell Z0.5, Germany). Another skin sample underwent histopathological examination (18-20). A tensiometer measures the breaking strength in $\mathrm{N}$ (Newton), which is called tensile strength.

\section{Circular excision wound model}

The circular excision wound model was used for the evaluation of the wound contraction. The mice were anaesthetized with 0.02 cc Xylazine (2\% Alfazine ${ }^{\circledR}$ ) and 0.08 cc Ketamine $(10 \%$ Ketaso( $\left.{ }^{\circledR}\right)$ and the back hairs were depilated by shaving. A circular wound was created on the dorsal interscapular region of each animal by excising the skin with a $5 \mathrm{~mm}$ biopsy punch; wounds were left open. The extracts, the reference drug (Madecassol${ }^{\circledR}$ Bayer) and the vehicle ointments were applied topically once a day until the wounds of one group were completely healed. The progressive changes in the wound area were monitored by a camera (Fuji, S20 Pro, Japan) every other day. Later, wound area was measured by using AutoCAD program. Wound contraction was calculated as the percentage of the reduction in the wounded area. For the histopathological examination, a specimen sample of tissue was removed from the healed skin of each group of mice (20-22).

\section{Histopathology}

The cross-sectional full-thickness skin specimens from each group were collected at the end of the experiment to evaluate for the histopathological alterations. Samples were fixed in $10 \%$ buffered formalin, processed and blocked with paraffin and then sectioned into five micrometer sections and stained with hematoxylin \& eosin (HE) and Van Gieson (VG) stains. The tissues were examined by the light microscope (Olympus CX41 attached Kameram ${ }^{\circledR}$ Digital Image Analyze System) and graded subjectively as mild $(+)$, moderate $(++)$ and severe $(+++)$ for epidermal or dermal re-modeling. Re-epithelization or ulcus in epidermis; fibroblast proliferation, mononuclear and/or polymorph nuclear cells, neovascularization and collagen depositions in the dermis were analyzed to score the epidermal or dermal re-modeling. At the end of the examination, obtained results were combined and staged for wound healing phases as inflammation, proliferation, and remodeling in all groups (20).

\section{Statistical analysis of the data}

The data on percentage wound healing was statistically analyzed using one-way analysis of variance (ANOVA). A $p$-value $\leq 0.05$ was considered statistically significant. Histopathologic data were considered to be nonparametric (20).

\section{RESULTS AND DISCUSSION}

In the present study, the diethyl ether extracts of eight different species of the liverworts growing in Turkey (Table 1) were investigated for their in vivo wound healing activity. The wound healing activity was evaluated by using linear incision

\section{Table 1. The herbarium numbers and collection sites of the liverworts growing in Turkey}

\begin{tabular}{|c|c|c|c|}
\hline Family & Plant name & $\begin{array}{l}\text { Herbarium } \\
\text { number }\end{array}$ & Collection sites \\
\hline \multirow{3}{*}{ Aytoniaceae } & Mannia androgyna (L.) A. Evans & $\mathrm{C} 11 / 237$ & $\begin{array}{l}\text { Muğla; Milas, Kapıkırı Village, Heraclea Archaic City Ruins, on the rocks and } \\
\text { soil bank near the roadside, } 35 \mathrm{~m}\end{array}$ \\
\hline & $\begin{array}{l}\text { Plagiochasma rupestre (J.R. Forst et G. } \\
\text { Forst) Steph }\end{array}$ & $\mathrm{C} 11 / 226$ & $\begin{array}{l}\text { Muğla; Milas, Kapıkırı Village, Heraclea Archaic City Ruins, on the rocks and } \\
\text { soil ground, } 70 \text { m }\end{array}$ \\
\hline & Reboulia hemisphaerica (L.) Raddi & $\mathrm{C} 11 / 227$ & Aydın; Koçarlı, Mersin Belen road $5^{\text {th }} \mathrm{km}$, on the road in stream bank, $696 \mathrm{~m}$ \\
\hline \multirow{2}{*}{ Porellaceae } & Porella cordaeana (Huebener) Moore & $\mathrm{C} 11 / 223$ & Aydın; Koçarlı, Mersin Belen road $5^{\text {th }} \mathrm{km}$, on the road in stream bank, $696 \mathrm{~m}$ \\
\hline & Porella platyphylla (L.) Pfeiff & $\mathrm{C} 11 / 222$ & Aydın; Koçarlı, Mersin Belen road $5^{\text {th }} \mathrm{km}$, on the road in stream bank, $696 \mathrm{~m}$ \\
\hline Ricciaceae & Riccia fluitans L. & $\mathrm{C} 11 / 225$ & İzmir; Selçuk, Zeytinköy Village, Kazangöl Lake, 3 m \\
\hline Targioniaceae & Targionia hypophylla L. & $\mathrm{C} 11 / 236$ & $\begin{array}{l}\text { Muğla; Milas, Kapıkırı Village, Heraclea Archaic City Ruins, on the rocks and } \\
\text { soil bank near the roadside, } 30 \mathrm{~m}\end{array}$ \\
\hline
\end{tabular}


and circular excision wound models. The skin samples were also evaluated histopathologically.

As shown in Table 2, topical application of the ointment prepared with the ethereal extracts of the Reboulia hemisphaerica, Plagiochasma rupestre and Targionia

\begin{tabular}{lll}
$\begin{array}{l}\text { Table 2. Effects of the Liverworts extracts on linear incision } \\
\text { wound model }\end{array}$ & (Tensile strength \%) \\
Material & $\begin{array}{l}\text { Statistical Mean } \pm \\
\text { S.E.M. }\end{array}$ & 5.7 \\
\hline Vehicle & $9.60 \pm 2.13$ & - \\
\hline Negative control & $10.18 \pm 2.44$ & 13.3 \\
\hline Corsinia coriandrina & $10.88 \pm 2.02$ & - \\
\hline Mannia androgyna & $9.15 \pm 2.82$ & 5.1 \\
\hline Porella cordaeana & $10.09 \pm 1.68$ & 18.7 \\
\hline Porella platyphylla & $11.39 \pm 1.79$ & $38.3^{* *}$ \\
\hline Plagiochasma rupestre & $13.28 \pm 1.64$ & - \\
\hline Riccia fluitans & $9.47 \pm 2.17$ & $43.1^{* * *}$ \\
\hline Reboulia hemisphaerica & $13.74 \pm 1.10$ & $24.3^{*}$ \\
\hline Targionia hypophylla & $11.93 \pm 1.29$ & $58.8^{* * *}$ \\
\hline Madecassol ${ }^{\circledR}$ & $15.24 \pm 1.06$ &
\end{tabular}

${ }^{*}: p<0.05,{ }^{* *}: p<0.01,{ }^{* * *}: p<0.001$, S.E.M.: Standard error of the mean Percentage of tensile strength values: Vehicle group was compared to Negative control group; Extracts were compared to Vehicle group hypophylla onto the incised wounds demonstrated the best wound tensile strength by the highest values of 43.1,38.3, and $24.3 \%$, respectively.

The contraction values of the wounds on the circular excision wound model for vehicle, negative control, the ethereal extracts and reference drug treated group are shown in Table 3. The ethereal extracts of Reboulia hemisphaerica, Plagiochasma rupestre and Targionia hypophylla were found to have wound healing potential with the contraction values of 35.65 and $62.13 \% ; 27.94$ and $58.04 \%$; 31.48 and $39.78 \%$; respectively, on day 10 and 12 , while the vehicle and negative control groups and the extracts of the liverworts showed no statistically significant wound healing activity onto the incised wounds demonstrated the best wound tensile strength by the highest values of $43.1,38.3$, and $24.3 \%$, respectively.

Histopathological analysis showed that the ethereal extracts of Reboulia hemisphaerica, Plagiochasma rupestre and Targionia hypophylla treated groups demonstrated better healing with rapid re-epithelization. The data obtained in histopathological evaluation were in accord with the outcome of wound models used in the present study. Delay in wound healing processes were observed especially in the vehicle and negative control groups compared to others (Table 4, Figure 1).

Skin sections show the hematoxylin \& eosin (HE) stained epidermis and dermis in $A$, and the dermis stained with

Table 3. Effects of the Liverworts on circular excision wound model

\begin{tabular}{|c|c|c|c|c|c|c|c|}
\hline \multirow{2}{*}{ Material } & \multicolumn{7}{|c|}{ Wound area \pm S.E.M. (Contraction \%) } \\
\hline & 0 & 2 & 4 & 6 & 8 & 10 & 12 \\
\hline Vehicle & $20.17 \pm 2.21$ & $\begin{array}{l}17.22 \pm 1.86 \\
(1.37)\end{array}$ & $\begin{array}{l}16.65 \pm 2.01 \\
-\end{array}$ & $\begin{array}{l}15.03 \pm 2.15 \\
-\end{array}$ & $\begin{array}{l}11.08 \pm 1.53 \\
(11.29)\end{array}$ & $\begin{array}{l}7.91 \pm 1.42 \\
(10.01)\end{array}$ & $\begin{array}{l}3.67 \pm 0.32 \\
(8.48)\end{array}$ \\
\hline Negative control & $19.67 \pm 2.18$ & $17.46 \pm 1.99$ & $16.59 \pm 1.95$ & $14.88 \pm 1.83$ & $12.49 \pm 1.85$ & $8.79 \pm 1.42$ & $4.01 \pm 1.19$ \\
\hline Corsinia coriandrina & $19.44 \pm 1.80$ & $\begin{array}{l}16.03 \pm 1.86 \\
(6.91)\end{array}$ & $\begin{array}{l}14.90 \pm 2.10 \\
(10.51)\end{array}$ & $\begin{array}{l}13.13 \pm 2.14 \\
(12.64)\end{array}$ & $\begin{array}{l}9.49 \pm 1.31 \\
(14.35)\end{array}$ & $\begin{array}{l}6.22 \pm 1.37 \\
(21.37)\end{array}$ & $\begin{array}{l}2.93 \pm 0.25 \\
(20.16)\end{array}$ \\
\hline Mannia androgyna & $19.40 \pm 2.77$ & $\begin{array}{l}17.03 \pm 1.73 \\
(1.10)\end{array}$ & $\begin{array}{l}17.01 \pm 1.86 \\
-\end{array}$ & $\begin{array}{l}14.19 \pm 1.92 \\
(5.59)\end{array}$ & $\begin{array}{l}10.20 \pm 1.34 \\
(7.94)\end{array}$ & $\begin{array}{l}7.77 \pm 1.39 \\
(1.77)\end{array}$ & $\begin{array}{l}3.51 \pm 0.88 \\
(4.36)\end{array}$ \\
\hline Porella cordaeana & $19.59 \pm 1.96$ & $\begin{array}{l}17.39 \pm 1.25 \\
-\end{array}$ & $\begin{array}{l}16.72 \pm 2.16 \\
-\end{array}$ & $\begin{array}{l}14.61 \pm 1.89 \\
(2.79)\end{array}$ & $\begin{array}{l}10.51 \pm 1.39 \\
(5.14)\end{array}$ & $\begin{array}{l}7.41 \pm 1.26 \\
(6.32)\end{array}$ & $\begin{array}{l}3.71 \pm 0.59 \\
-\end{array}$ \\
\hline Porella platyphylla & $19.27 \pm 1.53$ & $\begin{array}{l}15.64 \pm 1.07 \\
(9.18)\end{array}$ & $\begin{array}{l}14.05 \pm 1.48 \\
(15.62)\end{array}$ & $\begin{array}{l}13.26 \pm 2.36 \\
(11.78)\end{array}$ & $\begin{array}{l}9.70 \pm 1.47 \\
(12.45)\end{array}$ & $\begin{array}{l}6.60 \pm 1.11 \\
(16.56)\end{array}$ & $\begin{array}{l}2.96 \pm 0.34 \\
(19.35)\end{array}$ \\
\hline Plagiochasma rupestre & $20.68 \pm 2.41$ & $\begin{array}{l}15.02 \pm 1.40 \\
(12.78)\end{array}$ & $\begin{array}{l}13.44 \pm 1.96 \\
(19.28)\end{array}$ & $\begin{array}{l}11.89 \pm 2.18 \\
(20.89)\end{array}$ & $\begin{array}{l}9.79 \pm 1.15 \\
(11.64)\end{array}$ & $\begin{array}{l}5.70 \pm 1.10 \\
(27.94)\end{array}$ & $\begin{array}{l}1.54 \pm 0.09 \\
(58.04)^{\star *}\end{array}$ \\
\hline Riccia fluitans & $19.90 \pm 2.55$ & $\begin{array}{l}16.81 \pm 1.56 \\
(2.38)\end{array}$ & $\begin{array}{l}16.08 \pm 2.03 \\
(3.42)\end{array}$ & $\begin{array}{l}14.80 \pm 1.90 \\
(1.53)\end{array}$ & $\begin{array}{l}10.76 \pm 1.60 \\
(2.89)\end{array}$ & $\begin{array}{l}8.05 \pm 1.56 \\
-\end{array}$ & $\begin{array}{l}3.84 \pm 0.29 \\
-\end{array}$ \\
\hline Reboulia hemisphaerica & $20.56 \pm 2.06$ & $\begin{array}{l}15.58 \pm 1.44 \\
(9.52)\end{array}$ & $\begin{array}{l}14.07 \pm 1.65 \\
(15.49)\end{array}$ & $\begin{array}{l}12.21 \pm 2.23 \\
(18.76)\end{array}$ & $\begin{array}{l}8.84 \pm 1.17 \\
(20.22)\end{array}$ & $\begin{array}{l}5.09 \pm 1.16 \\
(35.65)^{\star}\end{array}$ & $\begin{array}{l}1.39 \pm 0.08 \\
(62.13)^{\star *}\end{array}$ \\
\hline Targionia hypophylla & $19.78 \pm 2.23$ & $\begin{array}{l}15.41 \pm 1.85 \\
(10.51)\end{array}$ & $\begin{array}{l}14.62 \pm 1.29 \\
(12.19)\end{array}$ & $\begin{array}{l}12.19 \pm 1.76 \\
(18.89)\end{array}$ & $\begin{array}{l}8.36 \pm 1.69 \\
(24.55)\end{array}$ & $\begin{array}{l}5.42 \pm 1.31 \\
(31.48)^{\star}\end{array}$ & $\begin{array}{l}2.21 \pm 0.14 \\
(39.78)^{\star}\end{array}$ \\
\hline Madecassol@ & $19.31 \pm 1.65$ & $\begin{array}{l}13.89 \pm 1.14 \\
(19.34)\end{array}$ & $\begin{array}{l}13.24 \pm 1.79 \\
(20.48)\end{array}$ & $\begin{array}{l}9.51 \pm 1.06 \\
(36.73)^{\star}\end{array}$ & $\begin{array}{l}3.19 \pm 0.75 \\
(71.21)^{\star * *}\end{array}$ & $\begin{array}{l}1.17 \pm 0.43 \\
(85.21)^{\star \star *}\end{array}$ & $\begin{array}{l}0.00 \pm 0.00 \\
(100.00)^{\star * *}\end{array}$ \\
\hline
\end{tabular}

${ }^{*}: \mathrm{p}<0.05,{ }^{* *}: \mathrm{p}<0.01,{ }^{* * *}: \mathrm{p}<0.001$, S.E.M.: Standard error of the mean

Percentage of contraction values: Vehicle group was compared to Negative control group, Extracts were compared to Vehicle group. 
Van Gieson (VG) in B. The original magnification was $\times 100$ and the scale bars represent $120 \mu \mathrm{m}$ for figures in $\mathrm{A}$, and the original magnification was $\times 400$ and the scale bars represent $40 \mu \mathrm{m}$ for B. Data are representative of 6 animal per group. 1. Vehicle; 2. Negative Control; 3. Corsinia coriandrina; 4. Mannia androgyna; 5. Porella cordaeana; 6. Porella platyphylla; 7. Plagiochasma rupestre, 8. Riccia fluitans, 9. Reboulia hemisphaerica, 10. Targionia hypophylla, 11. Madecassol ${ }^{\circledR}$. Arrows pointing events during wound healing; s: scab, u: ulcus, re: re-epithelization, f: fibroblast, c: collagen, mnc: mononuclear cells, pmn: polymorphonuclear cells, nv: neovascularization.

A large number of people are suffered from wounds especially from chronic wounds. In spite of advances in medicine, the availability of drugs which is curative in the wound process is still limited (7). Nowadays, the natural products are potential sources for the development of the new drugs as well in the past. Wounds are physical injuries that result in an opening or breaking of the skin. Wound infections are the most common end, especially in developing countries because of poor hygienic conditions and also seriously reduce their quality of life. Thus, developing new wound healing agents are important in biological activity studies. The plant natural products can act as potent anti-inflammatory, antioxidant or anticancer agents. Antioxidant, antimicrobial and antiinflammatory activities help to promote wound healing and contribute skin regeneration. The mechanism of antioxidant compounds is the inhibition of lipid peroxidation and by way of radical scavenging activity, which prevent cell damage.
Antimicrobial activity is also important for the wound healing period, since the wound is more inclined to microbial attacks such as Staphylococcus aureus, Streptococcus pneumonia, Klebsiella pneumonia, which are caused infections and latency in wound area $(5,23)$.

Wound-healing is a complex multifactorial process that results in the contraction and closure of the wound and restoration of a functional barrier $(24,25)$. Thus, wound-healing process consists of several phases, including homeostasis, inflammation, cellular proliferation and migration of different cell types as resulting remodeling phase. The first response is inflammation as a defense mechanism of the tissue, which provides a resistance to the microbial contaminations. However, a long duration in the inflammatory phase causes a delay in healing process. Skin fibroblast proliferation is important in tissue repair as fibroblasts are involved in migration, proliferation, contractions and collagen production. The process of re-epithelialization occurs in the proliferatives phase. The final phase of the wound healing is called as maturation and remodeling phase. The completion of healing is ended by collagen coverage $(3,5,6,23,26)$.

The liverworts have the wide range of endemic species, which include many interesting constituents with important biological activities. Principally, the liverworts contain a large amount of mono-, sesqui- and diterpenoids, and aromatic compounds with unique structures. However, the reason of the increasing interest of the liverworts is for their structurally impressive constituents exhibiting high therapeutic effects as cytotoxic, antitumor, antimicrobial, antifungal, antifeedant,

\section{Table 4. Wound healing processes and healing phases of the experimental group animals}

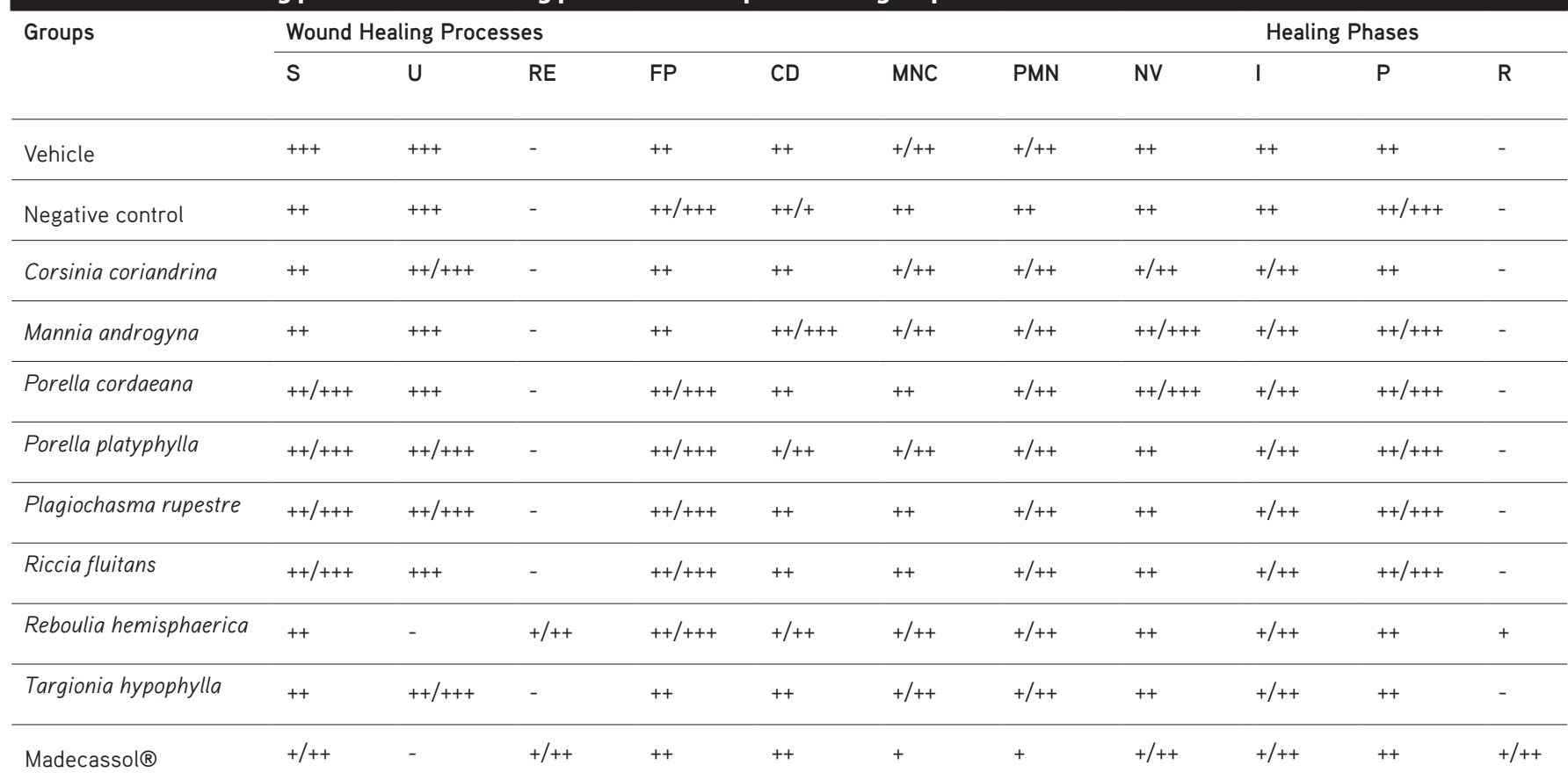

*HE and VG stained sections were scored as mild (+), moderate (++) and severe (+++) for epidermal and/or dermal re-modeling. S: Scab, U: Ulcus, RE: Re-epithelization, FP: Fibroblast proliferation, CD: Collagen depositions, MNC: Mononuclear cells, PMN: Polymorphonuclear cells, NV: Neovascularization, I: Inflammation phase, P: Proliferation phase, R: Re-modeling phase 


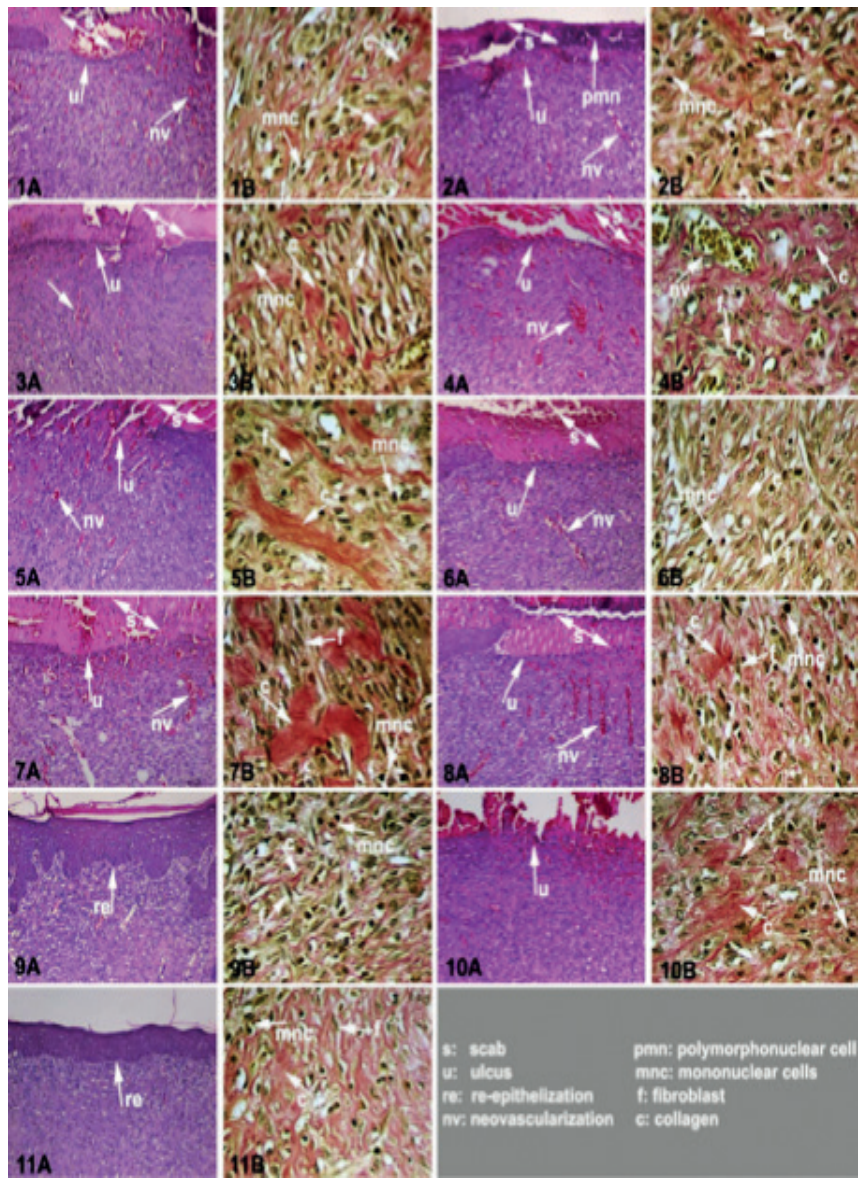

Figure 1. Histopathological view of wound healing and epidermal/dermal re-modeling in the vehicle, negative control, extracts and reference ointment Madecassol ${ }^{\circledR}$ administered animals

insecticidal, muscle relaxing, some enzyme inhibitory and apoptosis inducing activities (11-13,27).

There is not much investigation as in vivo biological activity studies on the most active species of Plagiochasma rupestre and Reboulia haemispherica and Targionia hypophylla as well as ethnomedicinal usages of these species (11). However, another species of the Plagiochasma. Plagiochasma appendiculatum (Aytoniaceae) used by Gaddi tribe in India ethnomedicinally for treating skin diseases has been found potent wound healing activity as evident from the wound contraction and increased tensile strength $(14,16)$. It was also found that $P$. appendiculatum extract possesses potent antioxidant activity by inhibiting lipid peroxidation and increase in the super oxide dismutase (SOD) and catalase (14). Moreover, according to the records, the liverworts are used for the cure of cuts, fractures, burns, bruises, open wounds and snakebites. Especially in China, the mixture of Marchantia polymorpha and Conocephalum conicum with vegetable oils is used for bites, burns, cuts, eczema, and wounds (10).

According to the phytochemical studies on the liverworts, a wide variety of the terpenoid derivatives such as mono, sesqui- and diterpenes which are mainly accumulated in nonpolar fractions as well as aromatic and phenolic compounds have been isolated from too many liverworts collected different places of the world (11). In thin layer chromatography and qualitative analysis by using chemical reagent, these type components are detected in the ethereal extracts of the Turkish liverworts. In our previous study GC analysis was conducted on the ethereal extracts of Reboulia hemisphaerica and $\beta$-microbiotene $(12.43 \%)$, grimaldone (8.62\%), $\beta$-caryophyllene $(4.91 \%)$ and cis- $\beta$-elemene $(4.14 \%)$ were determined as the major components (16). In previous studies it was demonstrated that terpenic compounds possess antimicrobial, anticarcinogenic, antioxidant, antiinflammatory, analgesic and wound healing activities (2830). Eventually, the effect might be attributed to the mainly terpenic compounds. Moreover, it is obvious that phenolics have potent antioxidant and anti-inflammatory effects, which are the main principles in the wound healing effect (11).

\section{CONCLUSION}

The ethereal extracts of the liverwort species growing in southern part of Turkey such as Riccia fluitans, Porella cordaeana, Porella platyphylla, Corsinia coriandrina, Mannia androgyna, Reboulia hemisphaerica. Plagiochasma rupestre, Targionia hypophylla were evaluated comparatively for the wound-healing activity. Experimental results indicated that the ethereal extracts of Reboulia hemisphaerica, Plagiochasma rupestre and Targionia hypophylla has been potent wound healing capacity in this test system. The rest of the species did not show any remarkable wound healing effect. In the present study, wound-healing activity of the liverwort extracts supported the traditional use of these species. However, further studies are need to isolate the pharmacologically active compounds contributing to the wound-healing properties of the liverwort species. Moreover, wild species of the plants that have no information about their usages are also waiting to be investigated for new agents to heal the illnesses.

\section{REFERENCES}

1. Adams M, Berset C, Kessler M, Hamburger M, Medicinal herbs for the treatment of rheumatic disorders--a survey of European herbals from the 16th and 17th century, J Ethnopharmacol 121, 343-359, 2009.

2. Butler MS, The role of natural product chemistry in drug discovery, $J$ Nat Prod 67, 2141-2153, 2004.

3. Nair HB, Sung B, Yadav VR, Kannappan R, Chaturvedi MM, Aggarwal $\mathrm{BB}$, Delivery of antiinflammatory nutraceuticals by nanoparticles for the prevention and treatment of cancer, Biochem Pharmacol 80 , 1833-1843, 2010.

4. Verpoorte R, Kim HK, Choi YH, In: Plants as source of medicine in medicinal and aromatic plants, Ed(s): R.J. Bogers, L.E. Craker, D. Lange, 2006.

5. Kumar B, Vijayakumar M, Govindarajan R, Pushpangadan P, Ethnopharmacological approaches to wound healing exploring medicinal plants of India, J Ethnopharmacol 114, 103-113, 2007.

6. Adetutu A, Morgan WA, Corcoran O, Ethnopharmacological survey and in vitro evaluation of wound-healing plants used in Southwestern Nigeria, J Ethnopharmacol 137, 50-56, 2011. 
7. Inngjerdingen K, Nergard CS, Diallo D, Mounkoro PP, Paulsen BS, An ethonopharmacological survey of plants used for wound healing in Dogoland, Mali, West Africa, J Ethnopharmacol 92, 233-244, 2004.

8. Namsa ND, Tag H, Mandal M, Kalita P, Das AK, An ethnobotanical study of traditional anti-inflammatory plants used by the Lohit community of Arunachal Pradesh, India, J Ethnopharmacol 125, 234-245, 2009.

9. Villegas LF, Fernandez ID, Maldonado H, Torres R, Zavaleta A, Vaisberg AJ, Hammond GB, Evaluation of the wound-healing activity of selected traditional medicinal plants from Peru, J Ethnopharmacol 55, 193-200, 1997.

10. Glime JM, Bryophyte Ecology. E-book, 2006.

11. Asakawa $Y$, In: Progress in the Chemistry of Organic Natural Products. Ed(s): A.D. Kinghorn, H. Falk, S. Gibbons, J. Kobayashi, Springer, New York, 1995.

12. Asakawa $Y$, Chemosystematics of the Hepaticae, Phytochemistry 65 , 623-669, 2004.

13. Asakawa Y, Potential source of medicinal plants, Curr Pharm Des 14 , 3067-3088, 2008.

14. Singh $M$, Govindarajan $R$, Nath $V$, Rawat AK, Mehrotra $S$, Antimicrobial, wound healing and antioxidant activity of Plagiochasma appendiculatum Lehm. et Lind. J Ethnopharmacol 107, 67-72, 2006.

15. Davis PH, Flora of Turkey and the East Aegean Islands, Supplement 2. University Press, Edinburgh, 2000.

16. Tosun A, Kupeli Akkol E, Suntar I, Ozenoglu Kiremit H, Asakawa Y, Phytochemical investigations and bioactivity evaluation of liverworts as a function of anti-inflammatory and antinociceptive properties in animal models, Pharm Biol 51, 1008-1013, 2013.

17. Ehrlich HP, Hunt TK, The effect of cortisone and anabolic steroids on the tensile strength of healing wounds, Ann Surg 57, 117, 1968.

18. Lodhi S, Pawar RS, Jain AP, Singhai AK, Wound healing potential of Tephrosia purpurea (Linn.) Pers. in rats, J Ethnopharmacol 108, 204210, 2006.

19. Suguna L, Singh S, Sivakumar P, Sampath P, Chandrakasan G, Influence of Terminalia chebula on dermal wound healing in rats, Phytother Res 16, 227-231, 2002.

20. Suntar I, Baldemir A, Coskun M, Keles H, Akkol EK, Wound healing acceleration effect of endemic Ononis species growing in Turkey, $\mathrm{J}$ Ethnopharmacol 135, 63-70, 2011.
21. Sadaf F, Saleem R, Ahmed M, Ahmad SI, Navaid ul Z, Healing potential of cream containing extract of Sphaeranthus indicus on dermal wounds in guinea pigs, J Ethnopharmacol 107, 161-163, 2006.

22. Tramontina VA, Machado MA, Nogueira Filho Gda R, Kim SH, Vizzioli MR, Toledo S, Effect of bismuth subgallate (local hemostatic agent) on wound healing in rats, Histological and histometric findings. Braz Dent J 13, 11-16, 2002.

23. Pattanayak SP, Sunita P, Wound healing, anti-microbial and antioxidant potential of Dendrophthoe falcata (L.f) Ettingsh, J Ethnopharmacol 120, 241-247, 2008.

24. Hanna JR, Giacopelli JA, A review of wound healing and wound dressing products, J Foot Ankle Surg 36, 2-14; discussion 79, 1997.

25. Karishan $P$, Focus on: Wound healing, chronic pain and inflammation. The scientific study of herbal wound healing therapies: Current state of play, Curr Anaesth Crit Care 17, 21-27, 2006.

26. Aravindaram K, Yang NS, Anti-inflammatory plant natural products for cancer therapy, Planta Med 76, 1103-1117, 2010.

27. Crandall-Stotler BJ, Stotler FRE, Evolutionary trends in the simple thalloid liverworts (Marchantiophyta, Jungermanniopsida subclass Metzgeriidae), Taxon 54, 299-316, 2005.

28. Adams S, Thrash TP, Methods for wound treatment and healing using limonene-based compositions. International Application Published Under the Patent Cooperation Treaty, W02010/062933 A1, 2010.

29. Edris $A E$, Pharmaceutical and therapeutic potentials of essential oils and their individual volatile constituents: A review, Phytother Res 21, 308-323, 2007.

30. Takayama C, de-Faria FM, de Almeida AC, Valim-Araujo Dde A, Rehen CS, Dunder RJ, Socca EA, Manzo LP, Rozza AL, Salvador MJ, Pellizzon CH, Hiruma-Lima CA, Luiz-Ferreira A, Souza-Brito AR, Gastroprotective and ulcer healing effects of essential oil from Hyptis spicigera Lam. (Lamiaceae), J Ethnopharmacol 135, 147-155, 2011.

Received: 07.01.2016

Accepted: 25.02.2016 